\title{
Development of Musical Thinking in the Course of Training of Performing Musicians as a Pedagogical Problem
}

\author{
Irina S. Avramkova ${ }^{1, *}$, Marina G. Kruglova ${ }^{2}$, Irina S. Kazakova ${ }^{2}$, Artur A. Maksaev ${ }^{3}$, \\ Elizaveta E. Grushina ${ }^{3}$ \\ ${ }^{1}$ Department of Musical and Instrumental Mastering, Saint Petersburg State Pedagogical University, Russia \\ ${ }^{2}$ Department of Sociology and Philosophy of Music, Russian State Social University, Russia \\ ${ }^{3}$ Department of Philosophy, History, Cultural Theory and Arts, Moscow State Institute of Music Name after A.G. Schnittke, Russia
}

Received September 4, 2019; Revised October 23, 2019; Accepted October 26, 2019

Copyright $\mathrm{O} 2019$ by authors, all rights reserved. Authors agree that this article remains permanently open access under the terms of the Creative Commons Attribution License 4.0 International License

\begin{abstract}
From young musicians taking their first steps in music to professionals with higher education, the level of development and maturity of thinking affect the quality of performance and understanding of music. In order to comprehend the artistic conception of works created at the end of the 20th and the beginning of the 21st centuries, future performing musicians need a high level of thinking during performance, analysis, listening to and creation of musical compositions. Development of musical thinking is inextricably connected with practical activities of students in the classroom and their independent work. The phenomenon of musical thinking requires a comprehensive pedagogical approach, especially in terms of higher education when the foundations for professional competencies of future performing musicians are being built. Therefore, this article looks at the development of thinking in performing musicians in the course of their studies at higher education institutions. It explores the specific features of musical thinking, conditions and methods of its development as a fundamental ability of a musician for their professional activity.
\end{abstract}

Keywords Musical Thinking, Professional Training, Music Teacher, Performer, Pedagogy

\section{Introduction}

Music thinking is the ability to perceive, recognize and imagine music images and understand the semantics of musical pieces, which is reflected in premeditation of the performer's interpretation of the piece, as well as in the skills required to incarnate one's vision of its imagery and semantic content while playing the instrument. Performing art requires "thinking through images" [1], since the content of a musical piece is represented by ideas, emotions, images and objects [2]. Musical thinking is seen as a form of expressing a creative idea - the mental prototype of the artistic content of a musical composition which predetermines its interpretation by a performer. Therefore, great attention is paid to musical thinking in the course of professional training of students at higher education institutions.

The issue of development of creative abilities and musical reflection is multifaceted and requires systematic research. The stages of this research are as follows: clarification of such concepts as thinking, creativity and creative abilities, identification of the principles governing the development of these personal qualities, building a model of development of creative abilities, studying the mechanisms of mental activity typical of musicians and the ways of improving their heuristic and figurative thinking. Besides, in order to accomplish the pedagogical task of developing musical thinking, it is necessary to analyze and identify the effective methods, principles and technologies of intellectual and creative personal development during study at a higher education institution.

It is common knowledge that creating and thinking processes are not identical. The aim and results of creative activity are something new (a composition, an interpretation, an idea or a solution), the quest for which encourages the development of student's inner creative potential. Consequently, this person transforms himself/herself and the world around him/her. In terms of the music performing art, each interpretation of a musical piece that appears in the course of theoretical reflection and practical exploration is new. However, in order to acquire 
the skill of creating new concepts, it is necessary to obtain the ability to analyze musical semantics.

\section{Methods}

The phenomenon of musical thinking, an analytical and creative approach to musical compositions was subject to scientific and philosophical exploration in the first half of the last century. The issue of developing musical thinking has been examined in a historical retrospective and from a psychological perspective [3-6] in the works by M.G. Aranovskii [7,8], I. Lyashenko [9], V.V. Medushevskii [1], O.V. Sokolov [10], A.N. Sokhor [11] and V.N. Kholopova [2]. Practical methods of developing musical thinking have been addressed in works by the following pianists and teachers: Yu.B. Aliev [12], N. Savshinskii [13], L.G. Ushakova [14], G.M. Tsypin [6] and others. However, the complex nature of the subject matter dictates the need to take into consideration the theory of problem-based learning, as well as the theory and practice of music education in general.

In order to research this issue, it is reasonable to use the integrative, historical reconstruction, associative, analytical, experimental, statistical and other methods that provide a comprehensive approach to the phenomenon of musical thinking and effective search for the paths of its development. Together, they allow researchers to examine the context and motivation for musical thinking, the mechanisms and conditions of its functioning in the course of learning to play the piano, which helps to develop, assess and test both traditional and innovative methods of enhancing thinking as one of the key personal capabilities. However, the most promising approach to "development of the most accurate perception of the original text or a piece of music in the entirety of their content and meaning" [15] is the semantic approach.

\section{Results}

J. F. Herbart viewed the phenomenon of thinking in its "syncretic trinity of musical cogitation, perception and musical memory" [3]. It suggests a certain level of development of musical consciousness and cognitive skills. G. M. Tsypin points out that "the presence of the reasonable and logical component in musical thinking endows it with qualities typical of thinking in the common understanding of the term and extends it beyond the boundaries of sensual perception" [6]. N. P. Koptseva calls musical thinking "the highest form of the audio substance as a variety of the synthetic substance that combines sensuality and rationality in a dialectic unity" [16].

H. Riemann interpreted musical thinking as a variety of human mental activities in general. However, the scientist believed that "the process of musical thinking is distinguished by a few specific operational features and qualities, in accordance with which rhythm and harmony become the main components of musical compositions, while the melody, dynamics and agogics play the part of the main emotional and semantic aspect" [4]. In further studies devoted to musical thinking, it is highlighted that "highly developed musical thinking allows to get deep into music art, accumulate the most elaborated and complex artistic and poetic ideas and creative concepts" [17].

This skill is acquired as a result of studying musical semantics, which lies at the core of art criticism and represents the theoretical aspect of musical thinking [18]. As we see it, analyzing the semantics of musical compositions is an unavoidable and necessary stage when performing musicians study a piece of music even if this process is connected with the technical exploration of audio material. The complex nature of this phenomenon is explained by the lack of mechanisms for implementation of one's vision, image or feeling with certain expressive means. Being not a verbal language, audio substance allows approximate interpretation of connections between the semantic field and musical reality.

A vivid illustration is a streak of major surrounded by the atmosphere of quiet dynamics in F. Schubert's piano compositions. Schubert's major is full of quiet light which symbolizes internal human spiritual beauty and embodies the sun, light and air. At some point, it sounds tragically as an echo of eternal beauty. Schubert's contemporary, R. Schumann, used a totally different major in his works more earthly, sensual, open and tangible. In the works by late romanticists major sometimes becomes gloomy and sinister - consider the lover's theme in the 5th part of Symphonie Fantastique by H. Berlioz, which sounds in major as dancing at a witches' sabbath. As for impressionist composers, their major becomes colder and gains a neutral and detached sound shade.

Studies of musical semantics allow students to understand general cultural orientations, figurative and conceptual values, as well as artistic and aesthetic principles governing different kinds of art, styles and movements; expressive powers of various genres, rules and regulations existing in different periods, symbols, contexts and implications contained in musical pieces, specific features of the author's personal perception, their conceptual ideas, certain artistic tasks and directions in development of the performer's own interpretation of a piece. All of these data form a rich intellectual inventory and enhance the thinking processes of performing musicians while they are working on compositions.

Unlocking the semantics of a musical piece is encouraged by establishing the connections between its imagery and semantic content and extramusical circumstances, historico-cultural context and general artistic principles. Besides, it is necessary to take into consideration the processual nature and historical 
implications of the changes taking place in musical semantics [7]. It is also important to remember that semantics is formed at different interrelated levels of a musical piece - intonation and theme, genre, style, organization and composition.

Work on pieces of music represents the practical aspect of musical thinking related to familiarization with repertoire. This process is associated with certain difficulties and involves a few stages - from reading sheet music to a polished stage performance. Any piece of music performed by a great musician is always a carefully developed reconstruction without any foreign elements, which is why imitations or copying individual details are pointless. Lack of individuality in music can be determined by ear, hence the necessity to think in order to develop one's own listening and make a personal contribution to the performance of a particular opus.

The work on a composition moves from the whole to details, each of which is considered separately, and then all elements merge into a single image in the mind of a musician. The first contact with an unknown text reveals the character of music, specific features of the harmonic language, technical difficulties and rhythmic figurations, encouraging penetration into the form and content. At this point, the knowledge of theoretical subjects is important, such as music theory, harmony, analysis of musical forms and polyphony. Without these, musical thinking cannot be developed and performing is meaningless. The form of a musical composition, its structure, the character of topics and identification of the figurative nature of music are directly connected with the selection of technical and artistic expressive means.

The next stage of work is the resolution of technical issues. It involves virtuosity, music strokes as means of creating images, figuration and chordal techniques, purity and expressiveness of intonation, freedom of performance and sound production corresponding with the character of images, music genre and style. It is the most difficult and time-consuming, but necessary creative process that cannot be ignored by both novice and experienced musicians.

Other tasks include specification of the means of familiarization with the musical piece and performance peculiarities, consideration of possible challenges and ways of dealing with them and working on the imagery and interpretation of the piece. In order to go through this stage, it is necessary to examine a large amount of information, which is not just "swallowed" by students - rather, it is thought over, evaluated and connected with all elements of a complex system represented by a musical composition [19]. At all times music was a deep reflection of people's lives, their creative ideas and views, changes in psychology and mentality, attitude to beauty and cultural values in the surrounding world [5]. It is possible to comprehend all these aspects in the course of a thorough analysis of all elements of the music language, peculiarities of the genre, style, epoch and the composer's creative approach.

\section{Discussion}

Teachers point out the didactic reasonableness of introducing problem situations into the educational process: "Exposing students to real-life situations and facts that require theoretical explanation, organization of practical tasks, development of hypotheses, motivating students to compare and juxtapose their knowledge and consolidate it is an important pedagogical task" [6]. Problem situations are often present in musical compositions, especially in the modern styles of academic music. For example, in piano music by E. Denisov intonational turns, motifs, rhythmic patterns, melodic idioms and leading intonations that have contextual, if not symbolic, meaning, are semanticized.

Along with the introduction of the EDS intonational figure derived from the name of its author (Edison Denisov) into piano music, which symbolizes a deeply personal, intimate type of statement, this composer uses certain melodic turns in a semantic way to reinforce the expressiveness and content distinctness of the explored theme. The most common melodic structures in the author's musical palette are lamento intonations, motions borrowed from sixth romances, and especially frequent are the composer's favorite leading tones with a diminished fourth in the Rachmaninov style. In the tiny roll call of trills that appears in the melodic lines of the 14th Variation from the cycle "Variations On A Theme of Handel" against the backdrop of semi-improvisational texture reminding a romantic concert cadence, leading tones with a diminished fourth, along with a diminished third, enhance the elegiac shade of the piece.

Rhythmic patterns in piano compositions are also subject to semantization. A bright illustration is a musical piece entitled "Points and Lines". The temporal proportions of durations here perform an important conceptual function in depicting the symbolic images of "points": the exquisite proportions of sounds create a pointillist texture where individual points emerge every now and then, whereas the lines are represented by long sounds, intervals and chords. Pauses inside rhythmic patterns denote moments of silence that appear in the dialog between the "points" and "lines". Their sound representation reminds paintings by $\mathrm{P}$. Mondrian, cubists and abstractionists.

Musical pieces by Denisov also contain a lot of special theme-related texture elements - distinctive rustling motifs comprising several sounds in a high register and quiet dynamics with comments "leggiero" and "dolcissimo". In such context, the rustling motifs interlay the "flying away" and "dispersing" codes of the compositions and symbolize usefulness, purity and clarity. In "Signs upon White" similar signs comprise the basis of the text; they are included in a different context of refined 
sounds and determine the nature of the piece's imagery their delicacy and fragility.

The modern music art in its variety creates a challenging environment for teachers and students who are learning to play musical instruments in terms of the development of performing skills and musical thinking through analysis of musical content, enthusiastic practicing and expressive performance of musical compositions. The irony is that modern students often experience difficulty studying academic music of the past, while they identify the logic of musical development, harmony and conceptual integrity in avant-garde or minimalist compositions more confidently.

In order to develop an all-around personality competent in the sphere of music that is able to enjoy listening, analyzing and performing music from different epochs and styles and understand how to do it, it is necessary to foster music students' interest in pieces of music by modern composers, as well as early compositions (baroque, classical, romantic), since such approach develops different thinking styles and principles typical of various epochs. For example, the Baroque epoch was characterized by monological thinking - presentation of one idea, one image and one feeling in a play, hence the usage of a single type of texture, single leading motif, single rhythmic pattern, etc. Conversely, musical avant-garde, especially the period of postmodernism, is characterized by the shift from monological thinking to "dialogical imagination", establishment of diversity, authenticity and equality of all meanings, images, concepts and interpretations [20].

In the course of analysis and technical exploration of a composition, the performer's musical thinking is developed due to the following factors:

- $\quad$ understanding the figurative and semantic content of the composition;

- looking for figurative analogies, comparisons and associations;

- feeling compassion for the emotions expressed in the piece;

- choice of one's own interpretation of the opus;

- building the form of the composition and looking for the logic of its development;

- analysis of harmony, rhythmics, melodics, agogics, texture and other expressive means and patterns in the structure of the composition.

In his work devoted to the methodology of problem-based and creative introduction of music to students [12], Yu. B. Aliev writes that thinking activity starts from setting "a training task that requires searching activity" [12]. It is a task needing a solution that initiates the thinking process by launching the mechanism of its development, broadening the outlook and establishment of personal general artistic culture. A problem situation stimulates the development of musical thinking in students. Therefore, it is necessary to create practical tasks for students' independent work aimed at the development of musical thinking.
Some examples of such tasks could determine the style of musical compositions by ear, listen to a cycle of musical pieces not listed in the academic program and write down your thoughts, analyze what caused them (the background, orchestration, tonal quality, the composer's style), create a visual backdrop for a composition referring to a painting or a literary piece, compose a cadence for the Piano Concerto No. 22 by W.A. Mozart, perform the same piece in different imagined lighting: red, purple and blue, record a video of the performance and provide it to the group to guess the imagined color.

Musical thinking is necessary for any kind of musical and creative activity, especially the analysis and composition of musical works. However, in performing arts, thinking determines the high result of creative activity not only technically, but artistically and aesthetically. The difference between performances, subject to highly and poorly developed musical thinking, is apparent, for example, in performances by amateur and professional musicians. The difference is noticeable even to ordinary people. Poorly developed thinking does not allow a musician to perform a composition technically completely and without hesitation and, most importantly, to play the music expressively, causing the audience to experience a strong emotional response, as well as to create a complete artistic image and express the essence of the musical idea, the presentation of which can take the form of a plot. Possessing highly developed musical thinking, a musician plays technically completely and without hesitation (cognitive abilities allow them to memorize musical notes and successfully perform difficult passages), expressively (cognitive abilities allow them to use different techniques and a wide arsenal of the expressive capabilities of the instrument). Most importantly, they are able to create a complete artistic image (cognitive abilities allow them to understand and express this image based on the nature of the music and the direction of its development) and the musical idea of the composition (cognitive abilities allow them to consciously embody the composer's intention: not just to recreate the composition, but to find its essence, highlight the features of the image and play out the action that occurs in this image).

\section{Conclusions}

Pedagogical theorists have created and practicing teachers have implemented universal practical methods and technologies of development of students' figurative and visual thinking based on student-centered approach, which can improve the effectiveness of mental processes in the course of learning to play the piano or sing. Each music student studying to become a professional performer will find an individual way to cope with anxiety before the concert or create a unique original interpretation of a musical piece together with their mentor.

Undoubtedly, purposeful improvement of thinking 
provides unlimited opportunities for the development of creative abilities, music and performing competencies and improvement of intellectual and spiritual culture of a future performing musician.

\section{REFERENCES}

[1] V. V. Medushevsky. Dukhovno-nravstvennyi analiz muzyki [The spiritual and ethical analysis of music], Kompozitor, Moscow, 90, 2007.

[2] V. Kholopova. Muzyka kak vid iskusstva. Uchebnoe posobie [Music as a kind of art. A study guide], Lan, St. Petersburg, 2002.

[3] J. F. Herbart. Psikhologiya [Psychology], Moscow: Izdatelskii dom "Territoriya budushchego", Moscow, 68, 2007

[4] D. K. Kirnarskaya. Psikhologiya spetsialnykh sposobnostei. Muzykalnye sposobnosti [The psychology of specific abilities. Music abilities], Talanty-XXI vek, Moscow, 95, 2004.

[5] V. I. Petrushin. Muzykalnaya psikhologiya [Music psychology], Vlados, Moscow, 1997.

[6] G. M. Tsypin. Psikhologiya muzykalnoi deyatelnosti: problemy, suzhdeniya, mneniya: Posobie dlya uchashchikhsya muz. otdelenii pedvuzov i konservatorii [The psychology of musical activity: problems, judgments, opinions: A study guide for music departments of pedagogical higher education institutions and conservatories], Interpraks, Moscow, 11, 98, 1994.

[7] M. G. Aranovskii. Myshlenie, yazyk, semantika [Thinking, language, semantics]. In M.G. Aranovski (Ed.), Problemy muzykalnogo myshleniya [The problems of musical thinking], Muzyka, Moscow, 90-128, 1974.

[8] M. G. Aranovskii (ed.). Problemy muzykalnogo myshleniya, Muzyka, Moscow, 1974.

[9] I. Lyashenko (ed.). Muzykalnoe myshlenie: sushchnost, kategorii, aspekty issledovaniya [Musical thinking: the essence, categories, research aspects], Muz. Ukraina, Kiev, 1989.

[10] O. V. Sokolov. O printsipakh strukturnogo myshleniya v muzyke [On principles of structured thinking in music]. In M.G. Aranovski (ed.), Problemy muzykalnogo myshleniya [The problems of musical thinking], Muzyka, Moscow, 153-176, 1974.

[11] A. N. Sokhor. Sotsialnaya obuslovlennost muzykalnogo myshleniya i vospriyatiya [The social framework of musical thinking and perception]. In M.G. Aranovski (ed.), Problemy muzykalnogo myshleniya [The problems of musical thinking], Muzyka, Moscow, 59-74, 1974.

[12] Yu. B. Aliev. Nastolnaya kniga shkolnogo uchitelya-muzykanta [The handbook for a school music teacher], Vlados, Moscow, 22, 2001.

[13] N. Savshinskii. Sekrety fortepiannogo masterstva: Mysli i aforizmy vydayushchikhsya muzykantov [The secrets of the piano art: Thoughts and quotes of outstanding musicians], Klassika-XXI, Moscow, 2001.

[14] L. G. Ushakova. Muzykalnoe myshlenie: stanovlenie predstavlenii, vzglyadov, teorii [Musical thinking: establishment of ideas, views, and theories]. Psikhologiya. Istoriko kriticheskie obzory i sovremennye issledovaniya, Vol. 5-6, 47-62, 2012.

[15] E. M. Akishina. Ot muzykalnoi semantiki - k muzykalnoi pedagogike [From musical semantics - to music pedagogy], Pedagogika iskusstva: an online scientific journal, Vol. 3, 2011, Online available from http://www.art-education.ru/si tes/default/files/journal_pdf/akishina-10-09-2011.pdf

[16] N. P. Koptseva. Muzykalnoe myshlenie i ego funktsii [Musical thinking and its functions], Pedagogika iskusstva: an online scientific journal, Vol. 1, 2012, Online available fromhttp://www.art-education.ru/electronic-journal/muzyk alnoe-myshlenie-i-ego-funkcii

[17] V. Kan-Kalik. Pedagogicheskoe obshchenie v rabote uchitelei-novatorov. Uchitelyu o pedagogicheskoi tekhnike [Pedagogical communication in the work of innovative teachers. Pedagogical techniques for teachers], Pedagogika, Moscow, 34, 1987.

[18] G. R. Taraeva. Problemy teorii muzykalnoi semantiki [The problems of theory of musical semantics]. Muzyka: obzor inform. (iss. 2), GBL, Moscow, 1988.

[19] I. M. Osmolovskaya. Slovesnye metody obucheniya: ucheb. posobie dlya stud. vyssh. ucheb. zavedenii [Verbal teaching methods: a study guide for students of higher educational institutions], Izdatelskii tsentr "Akademiya", Moscow, 2008.

[20] G. G. Kolomiets. Tsennost muzyki: filosofskii aspekt [The value of music: the philosophical aspect] (2nd ed.), Izdatelstvo LKI, Moscow, 2007. 